\title{
Gravity of Technology in Improvising the International Trade and Economic Growth
}

\author{
R. Vasuki, M. Sankar, N. Mathan Kumar
}

\begin{abstract}
The investigation looks at the effect of universal exchange on financial development of India utilizing exact examination Long run relationship estimation result shows a positive and noteworthy connection among fares and residential venture with GDP. The connection among Imports and swapping scale with GDP was seen as negative and measurably noteworthy. Short run relationship estimation result shows a positive and critical connection among fares and residential speculation with GDP, while the short run connection among imports and conversion scale was seen as negative, however factually irrelevant.
\end{abstract}

Keywords - Investigation, GDP, Financial Development

\section{INTRODUCTION}

Universal exchange alludes to the exchange crosswise over national limits. The developing volumes of worldwide exchange and bringing down of exchange obstructions have activated discussion and examination on the effect of universal exchange on financial development of nations. Verifiable approval has uncovered that universally dynamic nations will in general be more gainful than nations which produce for the residential market[1]-[7]. The connection between global exchange and financial development of a nation can be either positive or negative, what decides the idea of the relationship is the monetary systems set up to deal with the exchange.

\section{OBJECTIVES OF ADVERTISING}

a. Look at the effect of universal exchange on monetary development of India.

b. To decide the connection between the parts of universal exchange and monetary development of India.

c. To recognize the causal connection between the segments of universal exchange and monetary development of India.

\section{METHODOLOGY}

The examination utilized the Augmented Dickey Fuller (ADF) Test for unit root and Autoregressive Distributive Lag Model (ARDL) Co reconciliation approach which involves the Wald Test, Long run OLS estimation test, Error

Revised Manuscript Received on December 16, 2019

R.Vasuki, Department of Science and Humanities, Bharath Institute of Higher Education and Research, Chennai , India. Email: vasukiteacher@gmail.com

M.Sankar, Department of Science and Humanities, Bharath Institute of Higher Education and Research, Chennai , India. Email: sankar06.phd@gmail.com

N. Mathankumar, Department of Science and Humanities, Bharath Institute of Higher Education and Research, Chennai, India. Email: ma.aswinkumar18@gmail.com
Correction and Short run relationship estimation test, just as the Short run Causality test[8]-[15]. The information on the factors were sourced from The Handbook of Statistics on the Indian Economy and World Bank Database. The information was gathered for a time of 1980 to 2012.

\section{RESULTS AND DISCUSSIONS}

\section{A. Bound Test}

The primary test in the ARDL Model is the test for Co reconciliation. This test can be completed utilizing the Wald Test to test the invalid speculations of no co joining.

\section{B. Long Run Relationship Estimation}

Shows a negative and critical connection between swapping scale and imports with GDP. In any case, the connection among fares and residential speculation with GDP was seen as positive and huge[16]-[20]. The connection among swelling and GDP is negative, yet irrelevant

\section{Short Run Relationship Estimation}

In the wake of evaluating the since quite a while ago run coefficients, the last advance in the ARDL approach is the examination of Error Correction and estimation of short run coefficients. From, the consequence of since a long time ago run relationship is additionally affirmed by the huge Error Correction Term (ECT). The coefficient of the ECT shows the speed of modification for example following a stun, around $91 \%$ alteration towards the since a long time ago run harmony is finished in one year.

\section{Short Run Causality}

Causality testing is utilized to show the dynamic connection between time arrangement. It attempts to portray whether a period arrangement is valuable in estimating another. The examination utilized the Wald Testing deciding the short run causality between to the GDP. Be that as it may, there is no short run causality among imports and swelling to GDP[21]-[25]

\section{CONCLUSION}

From the study, our findings conforms to economic theories such as the Classical and Neoclassical theories that sees international trade as an engine of economic growth. The study is also in line with empirical literatures of Azees et al. (2014), Zahoor et al (2012) and Atoyebi et al. (2012). Policy recommendation to the government includes the enhancement of international trade participation by India. This can be achieved through 
creating the enabling atmosphere for trade promotion as well as increased participation of India in the world market government should encourage domestic investment through enhancement of gross capital formation because it boosts the economic growth of India.

\section{REFERENCES}

1) Vasanthi, S. \& Rabiyathul Basariya, S. 2019, "Influence of value analysis and cross training in industry", International Journal of Engineering and Advanced Technology, vol. 8, no. 6, pp. 1810-1811.

2) Velvizhi, R., Sri Gowtham, S. \& Jeya Priya, D. 2019, "Examination of early feedbacks for effective product retailing on E-commerce websites", International Journal of Engineering and Advanced Technology, vol. 8, no. 6 Special Issue 2, pp. 703-706.

3) Anuradha, C., Pothumani, S. \& Kavitha, R. 2019, "A novel method towards E-commerce", International Journal of Engineering and Advanced Technology, vol. 8, no. 6 Special Issue 2, pp. 535-538.

4) Thomas, J. \& Rabiyathul Basariya, S. 2019, "A study on the issues of financial ratio analysis", Indian Journal of Public Health Research and Development, vol. 10, no. 3, pp. 1079-1081.

5) Ramachandran, S. \& Rabiyathul Basariya, S. 2019, "Online marketing study on customer satisfaction and relationship", Indian Journal of Public Health Research and Development, vol. 10, no. 3, pp. 1072-1078.

6) Priya, R., Vinothini, G. \& Cor Jesu, C.D. 2019, "The mentor-protégé relationship for professional growth", Journal of Advanced Research in Dynamical and Control Systems, vol. 11, no. 9 Special Issue, pp. 1110-1119.

7) Jannifer Rani, N., Bina Pani, S. \& Nimisha, N.S. 2019, "A study on money back polices available in LIC", Journal of Advanced Research in Dynamical and Control Systems, vol. 11, no. 9 Special Issue, pp. 833-839

8) Saillaja, V., Jhansi Rani, K. \& Catherine, R. 2019, "Global marketing management planning and organization", Journal of Advanced Research in Dynamical and Control Systems, vol. 11, no. 9 Special Issue, pp. 489-493.

9) Saillaja, V., Jhansi Rani, K. \& Catherine, R. 2019, "The new phase of marketing information system", Journal of Advanced Research in Dynamical and Control Systems, vol. 11, no. 9 Special Issue, pp. 482-488.

10) Thoufiqulla \& Raju, D.V. 2019, "Perception of indian investor towards investment in mutual funds with special reference to mip funds", Journal of Advanced Research in Dynamical and Control Systems, vol. 11, no. 5, pp. 177-183.

11) Jasmine, K.R.M. \& Basariya, S.R. 2018, "A study on the customers benefits on mutual funds", International Journal of Civil Engineering and Technology, vol. 9, no. 4, pp. 45-48.

12) Vasanthi, S. \& Basariya, S.R. 2019, "Pros and cons of on the job training versus off the job training", International Journal of Scientific and Technology Research, vol. 8, no. 10, pp. 671-674.

13) Pavithra, J. \& Ganesan, M. 2016, "A study on awareness and impact of micro-financial schemes", International Journal of Applied Business and Economic Research, vol. 14, no. 8, pp. 5449-5460.

14) Pavithra, J., Dilli Babu, P. \& Ambuli, T.V. 2014, "A study on budgetary control at Maruti Service Masters, Chennai", International Journal of Applied Business and Economic Research, vol. 12, no. 2, pp. 151-161.

15) Gunaraja, T.M. \& Venkatrama Raju, D. 2018, "Determining factors of organisational climate with reference to leadership styles", International Journal of Mechanical Engineering and Technology, vol. 9, no. 9, pp. 1327-1332.

16) Gunaraja, T.M. \& Venkatrama Raju, D. 2018, "The role of job satisfaction and training of employees in determining organisational climate of a selected industry", International Journal of Civil Engineering and Technology, vol. 9, no. 8, pp. 1266-1269.

17) Aarathy, T.S. \& Raju, D.V. 2018, "Performance appraisal and its effects on employees with respect to it sector in Chennai city", International Journal of Civil Engineering and Technology, vol. 9, no. 6, pp. 1535-1538.

18) Aarathy, T.S. \& Raju, D.V. 2018, "Employee perception towards performance appraisal system in IT sector", International Journal of Mechanical Engineering and Technology, vol. 9, no. 5, pp. 131-135.

19) Porselvi, W., Jublee, D. \& Sivanesan, G. 2018, "A study on factors influencing adoption of technology and innovation in banking industry, tamilnadu, India", International Journal of Mechanical Engineering and Technology, vol. 9, no. 5, pp. 789-800.

20) Akessa, G.M. and Dhufera, A.G., 2015. Factors That Influences Students Academic Performance: A Case of Rift Valley University, Jimma, Ethiopia. Journal of Education and Practice, 6(22), pp.55-63.
21) Miller, G. and Shih, C.C., 1999. A faculty assessment of the academic rigor of on-and off-campus courses in agriculture. Journal of Agricultural Education, 40, pp.57-65.

22) Tsinidou, M., Gerogiannis, V. and Fitsilis, P., 2010. Evaluation of the factors that determine quality in higher education: an empirical study. Quality Assurance in education, 18(3), pp.227-244.

23) Farooq, M.S., Chaudhry, A.H., Shafiq, M. and Berhanu, G., 2011. Factors affecting students' quality of academic performance: a case of secondary school level. Journal of quality and technology management, 7(2), pp.1-14.

24) Fitsilis, P., Gerogiannis, V. and Anthopoulos, L., 2014. Ontologies for software project management: a review. Journal of Software Engineering and Applications, 7(13), p.1096.

25) Adams, J.D. and Jaffe, A.B., 1996. Bounding the effects of R\&D: an investigation using matched establishment-firm data(No. w5544). National bureau of economic research.

\section{AUTHORS PROFILE}

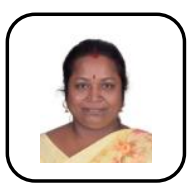

R.Vasuki Assistant Professor, Department of Science and Humanities, Bharath Institute of Higher Education and Research, Chennai, India.

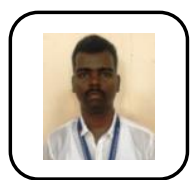

M.Sankar Assistant Professor, Department of Science and Humanities, Bharath Institute of Higher Education and Research, Chennai, India.

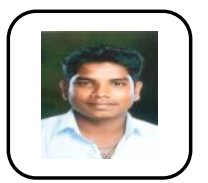

N. Mathankumar Assistant Professor, Department of Science and Humanities, Bharath Institute of Higher Education and Research, Chennai, India. 